\title{
İşten Ayrılma Niyeti ve Toksik Liderliğin Etkisi
}

\section{Dr. Rana Özyurt Kaptanoğlu ${ }^{1 *}$}

Gelis tarihi: 18.09.2019

Kabul tarihi: 07.01.2020

\section{Atıf bilgisi: \\ IBAD Sosyal Bilimler Dergisi \\ Sayl: $6 \quad$ Sayfa: $161-173$ \\ Yıl: 2020 Dönem: Kış}

This article was checked by Turnitin. Similarity Index 10\%

1 Türkiye, ranazoyurt77@gmail.com, ORCID ID 0000-0002-0341-4722

\section{* Sorumlu yazar}

ÖZ

Bireyin tedbirini alarak kendi isteği ile çalıştığı kurumdan ayrılması veya böyle bir karara varması yorumunu getiren işten ayrılma niyetine sahip bir iş görenin bu niyeti çoğunlukla işten ayrılma ile sonuçlanmaktadır. Ancak örgüt için personelin işten ayrılması genellikle negatif bir durumdur. Çalışan devir hızı, yetenek kaybı, ek işe alım ve eğitim masrafları bakımından bir örgüt için gerçek bir sorun teşkil etmektedir. Bir örgütte çalışanların çalışmaya başlamaları kadar işten ayrılmak istemeleri de doğal bir tutumdur. Bir çalışanın hayatının sonuna kadar aynı örgütte çalışması gibi bir zorunluluğu yoktur. Aynı örgüte uzun süreler çalışmak, çalışan ve örgüt bütünlüğü açısından gerekli olsa da bu gereklilik her zaman gerçekleştirilemeyebilir. Bu bağlamda çalışmada işten ayrılma niyetinin kapsamlı tanımı, bahsi geçen niyetin oluşma nedenleri, sonuçları, işten ayrılma niyetinin nasıl önlenebileceği ve toksik liderliğin işten ayrılma niyetine etkisine dair alan yazında inceleme yapılmıştır. Kurumlar için oldukça önemli olan bu konu hakkında yapılan çalışmanın hem gerçek hayata hem de alan yazında faydalı olacağı düşünülmektedir.

Anahtar Kelimeler: İşten Ayrılma Niyeti, Toksik Liderlik, iş. 


\section{Intending to Quit and the Effect of Toxic Leadership}

\section{Dr. Rana Özyurt Kaptanoğlu ${ }^{1 *}$}

First received: 18.09.2019

Accepted: 07.01.2020

\section{Citation:}

IBAD Journal of Social Sciences

Issue: 6

Pages: 161-173

Year: 2020

Session: Winter

This article was checked by Turnitin. Similarity Index $10 \%$

11Turkey, ranazoyurt77@gmail.com, ORCID ID 0000-0002-0341-4722

* Corresponding Author

\begin{abstract}
The intention of an employee who intends to leave the job by taking the precautionary measure of the individual or leaving his / her own voluntary work or making such a decision often results in leaving the job. However, for the organization, the dismissal of staff is often a negative situation. Employee turnover is a real problem for an organization in terms of loss of talent, additional recruitment and training costs. It is a natural attitude that employees in an organization want to leave as much as they start working. An employee does not have to work in the same organization until the end of his life. Although it is necessary to work for the same organization for long periods of time in terms of employee and organization integrity, this requirement may not always be fulfilled.Toxic behavior and the emotion it creates give employees both physically and emotionally. This naturally leads to organizational silence followed by a reduction in organizational ties and ultimately an intention to quit. There is a close relationship between intention to leave or stay in the organization and professional commitment. Some studies in this area show that individuals with high levels of professional commitment have lower tendency to quit and have higher commitment to their organizations.In this context, a comprehensive definition of intention to leave, reasons for the occurrence of this intention, results, how to prevent intention to leave and the effect of toxic leadership on intention to leave were examined in the literature. It is considered that this study, which is very important for institutions, will be beneficial both in real life and in literature.
\end{abstract}

Keywords: Intention to quit, Toxic Leadership, Business. 


\section{GIRIŞ}

Toksik liderlerin bulundukları ortamı negatif etkilemesi sonucunda üretim düşüklüğü ve işten ayrılma oranı yükseldiği görülmektedir. Bu ortamlarda genelde yeniliğe açık olma azalır, bireyler arasında çatışma oluşarak ve olumsuz bir ortam ortaya çıkar (Goldman, 2006, s. 734). Freeman ve Medoof (1985) sendikalaşmada ve yönetime karşı tek ses olmanın öneminden bahsetmiş olup, sendikalaşmanın çalışanların işten ayrılmalarını azalttığı açıklamıştır. Diğer bir çalışmada, örgüt ne kadar çalışanlarına işte duydukları memnuniyetsizliklerini dile getirme imkânı tanırsa, çalışanların da o oranda işte kaldıkları, işten ayrılmayı ise düşünmedikleri sonucuna ulaşılmıştır (Akt. Spencer, 1986, s. 488).

Buradan da anladığımız üzere örgütsel bağlılı̆ıı işten ayrılma niyeti, devamsızlık ve performans gibi olgularla yakından ilişkisi vardır. Bütün bu olguların gelişmesi sonucu da bireyde örgütsel vatandaşlık davranışları gözlemlenmektedir. Örgütün gelişimine maddi manevi en çok katkısı olan durumlardan biri de örgütsel vatandaşlık eğilimi yüksek bir çalışan profiline sahip olmaktır (Balay, 2000, s. 85).Çalışanların iş tatminsizliği yaşaması, performanslarının azalmasına ve hatta işten ayrılmalarına neden olabilir (Erdil vd., 2011, s. 19). Alanlarında deneyim kazanmış, iş tatmini yaşayan çalışanların örgüt içinde tutulması ve işten ayrılma niyetine engel olunması örgütün verimliliği açısından önem taşır (Poyraz ve Kama, 2008, s. 149).

\section{1. İşten Ayrılma Niyeti}

Bir örgütte çalışanların çalışmaya başlamaları kadar işten ayrılmak istemeleri de doğal bir tutumdur. Bir çalışanın hayatının sonuna kadar aynı örgütte çalışması gibi bir zorunluluğu yoktur. Aynı örgüte uzun süreler çalışmak, çalışan ve örgüt bütünlüğü açısından gerekli olsa da bu gereklilik her zaman gerçekleştirilemeyebilir (Fındıkçı, 2006:100). Çalışan ve işveren arasındaki sorunlar taraflar için kutuplaşmaya yol açmaktadır (Ertürk, 2009, s. 231).

Tett ve Meyer, (1993, s. 260), işten ayrılma niyetini bir örgütten bilinçli ve kararlı ayrılma isteği olarak tanımlamaktadır. 1900'lü yılların başlarından beri işten ayrılma konusunda birçok nitel ve nicel araştırma yapılmıştır (Cotton ve Tuttle, 1986, s. 56). Lee ve Mowday (1987, s. 723)'e göre işten ayrılma niyeti, işten ayrılma durumu ile sonuçlanmasa bile çalışanın verdiği bir sinyaldir. Bu sinyal sayesinde gerekli önlemler alınabilir. Hughes vd., (2010, s. 352) işten ayrılma niyetini bir karar verme süreci olarak ifade eder. $\mathrm{Bu}$ süreç örgütten ayrılma düşüncesi ile eylem arasındaki geçici bir bağlantıdır. Örgütten gelecekteki bir zamanda ayrılma ihtimali söz konusudur. İşten ayrılma niyeti, çalışanların örgütlerinde memnuniyetsizlik duymaları ve işten ayrılmayı düşünmeleri olarak da tanımlanabilir (Yıldırım vd., 2014, s. 35). İşten ayrılma niyeti konusunda yapılan araştırmalar, bu kavramı iş şartlarından tatmin olmayan çalışanların içine girmiş oldukları aktif ve yıkıcı eylem olarak ifade etmişlerdir (Onay ve Kılcı, 2011, s. 364). İşü̈cü piyasasında işgücü devri kaçınılmaz bir durumdur (Kirschenbaum ve Weisberg, 2002, s. 110). Bir örgütün ürün ve işgücü piyasasında sürdürülebilir rekabet üstünlüğü kazanabilmesi için işine bağlı ve işinden memnun çalş̧anlara ihtiyacı vardır (Joo ve Park, 2010, s. 482).

Bazı çalışma alanlarında rekabet ortamı daha fazla görülür, rekabetin sıkça görüldüğü bu piyasalarda kurumlar arasındaki farkı ortaya çıkaran insan kaynağının nasıl kullanıldığı ne şekilde elde tutulduğudur (Özer ve Günlük, 2010, s. 460). Diğer taraftan bir işletmede paylaşılan bir vizyon varsa bu durum ortak bir kimlik yaratır. Çalışanlar artık işletmeye onların işletmesi değil, bizim işletmemiz gözüyle bakarlar ve bu birlikte çalışmaya başlamak için atılmış ilk adım olur (Senge, 2011, s. 131).

Çalışan devir hızı, yetenek kaybı, ek işe alım ve eğitim masrafları bakımından bir örgüt için gerçek bir sorun teşkil eder (Loi vd., 2006, s. 101). İșten ayrılan çalışana işe alma ve eğitim için harcanan para ve zaman sonsuza kadar kaybedilmiş olur (Morrison, 2014, s. 99). Bu maliyetlerden kaçınmak isteyen örgütler çalışanlarını elde tutmayı sağlayacak politikalar uygulamalıdırlar (Yenihan vd., 2014, s. 39). Diğer bir anlatımla, işi bırakan her çalışanın yerine yenisinin getirilmesi yüksek maliyetlere yol açmaktadır. İşten ayrılmaların fazla olması, müşteri memnuniyetinin azalması, müşteri bağlılığının azalması ve gelirlerin azalmasıyla yakından ilgilidir, bu yüzden çalışanları işte tutabilmek önem taşımaktadır. 
İşten ayrılma kavramı çalışanın resmi protokoller ile bağlantısı olan kurum ile ilişiğini kesmesi olarak yorumlanmıştır. Bir müddettir bağlı bulunduğu kurumda çalışan bireyin kendi arzusu ile buradan ayrılması olarak belirtilmiştir (Lee vd., 2004, s. 712). Başka bir ifade ile de Gaertner bu konuyu çevresel içerikli bulmuş ve çalışanın kendi isteği ile belli bir sosyal ortamdan ayrılması olarak yorumlamıştır (Gaertner, 1999, s. 480). Bazı durumlarda işten ayrılmalar olumlu etki gösterse de genel olarak örgüt için maliyetli sonuçlar doğuran, olumsuz bir durumdur (Jackofsky, 1984, s. 74).

\section{2. İşten Ayrılma Niyeti Nedenleri}

Bireylerin işten ayrılma süreçleri incelendiğinde kurum içi kültürün, iş yaşamındaki sosyal iletişim ağının, kariyer olanaklarının, ücret ile ilgili beklentilerin ilk sıralarda gelen konular olduğu gözlemlenmektedir. Yozgat ve arkadaşlarının (2013, s. 520) yapmış oldukları çalışma sonucunda çalışanları çalışma süresinin iş performansı üzerindeki etkisi dikkate alındığında, eski çalışanların daha uzun süre çalışmaları için desteklenmesi ve erken emeklilik politikaları konusunda devletin uygulama yapmaması ve devletin kıdemli çalışanların işyerinde kalma niyetlerini arttırmak ve işe devamlarını sağlamak için teşvikler sunabileceği önerilmektedir. Diğer taraftan maaş ödemesi de çalişana belki daha sıkı çalışmak, daha güvenilir olmak ve işin gelişimine katkıda bulunmak için başka bir söz verme şeklidir (Rousseau ve McLean Park, 1993, s. 7). İşten ayrılma niyetinin nedenleri kısaca Tablo 1'de ki gibi özetlenebilmektedir:

Tablo 1. İsten Ayrılma Niyeti Nedenleri

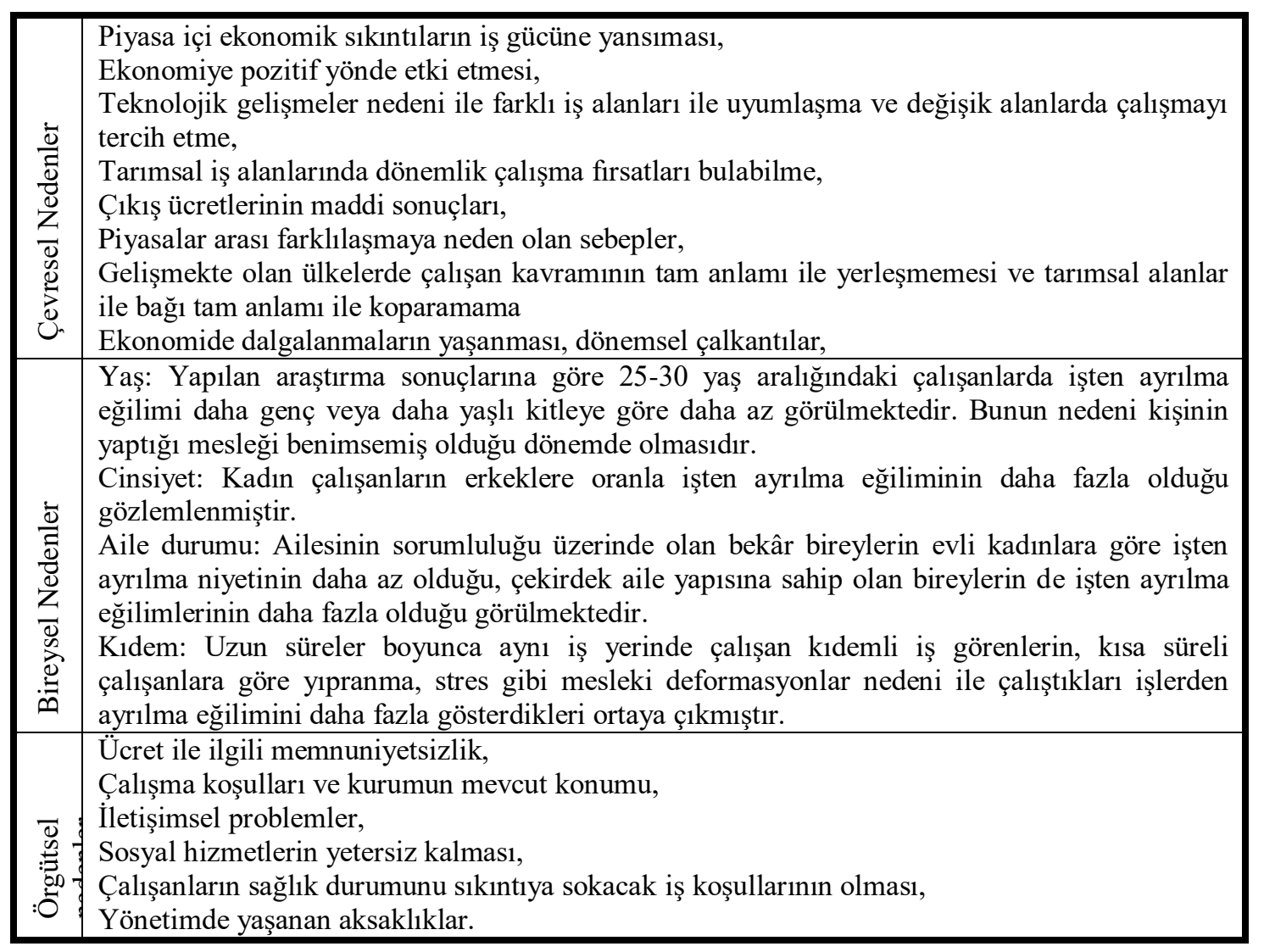

Kaynak: Şimşek, M., Akgemci, T., \& Çelik, A. (2008). Davranış Bilimlerine Giriş ve Örgütlerde Davranış. Ankara: Gazi Kitabevi, s. 55-65.

İşten ayrılma niyeti içine giren birey aslında kurum için ciddi kayıplar oluşturabilecek istifa sürecini beraberinde getirmektedir (Çarıkçı ve Çelikkol, 2009, s. 10). İşe girişler ve işten ayrılmaların sıklı̆̆ işten çalışan devir hızının yüksekliğini ifade eder (Yılmaz ve Halıcı, 2010, s. 95). İşten ayrılma niyeti bazı etkenler nedeniyle ortaya çıkabilir. Bu etkenler kişisel faktörler, örgütten kaynaklanan nedenler veya çevresel nedenler olabilir. İşten ayrılma niyetinin öncülleri birçok farklı perspektiften 
incelenmiştir. Bu çalışmaların büyük çoğunluğunda doğrudan öncüllere odaklanılmış ve bu öncüllerin işten ayrılma niyeti süreç modellerindeki üzerinde durulmuştur (Hemdi ve Nasurdin, 2006, s. 22). Literatür incelendiğinde işten ayrılma niyetinin üç ana başlıkta incelendiği görülmektedir:

\section{1. Örgütsel Nedenler}

Örgüt içi faktörlerin oluşmasında var olan yönetimin de etkisi çok fazladır. O yüzden bu etkilerin ortadan kaldırılmasında yöneticilere büyük görevler düşmektedir. Bir örgütte yönetsel uygulamalardan kaynaklanan problemler, çalışanların işten çıkarılmalarına veya kendi istekleriyle işten ayrılmalarına neden olabilir. Bununla birlikte yan gelirlerdeki yetersizlik ve ücretin yetersiz olması önemli unsurlardır (Tütüncü ve Demir, 2003, s. 149). Hemdi ve Nasurdin (2006, s. 22), örgüte duyulan güvenin işten ayrılma niyetine etkisi olduğunu ve örgüte duyduğu güven fazla olan çalışanın örgütten ayrılma ihtimalinin düşük olduğunu ileri sürmektedir. Bazı araştırmalar yapılan işin özellikleriyle işten ayrılma niyeti arasındaki ilişkiyi destekleyen bulgular bulmuştur (Chang vd., 2013, s. 5). Örgüt kaynaklı işten ayrılma niyeti üzerine pek çok çalışma yapılmıştır. Bu çalışmalar ve nedenler şu şekildedir:

\subsection{1. İş Tatmini}

Çalışanların gelecekte örgütten ve kendilerinden bekledikleri başarı seviyesi düşük ise başka iş olanakları arama niyeti içine girebilirler (Polat ve Meydan, 2010, s. 146). Çalışanlar örgüt içindeki kariyer firsatlarını değerlendirdiklerinde, kariyer firsatları sınırlı veya yoksa hayal kırıklığı yaşamamak için geri çekilebilirler. Her bir çalışan çekici bir çözüm olacak daha iyi bir kariyer firsatı sunan alternatif bir iş için işten ayrılabilir (Houkes vd., 2003, s. 428). Nitekim, örgüt içinde gelişme firsatları olmaması, o örgütten ayrılmak için makul bir neden olarak görülebilir. İşten ayrılıp gitmeler hem işçi hem de örgüt açısından bir maliyet getirir, işten ayrılma niyetinin, çalışanın örgütten destek alıp almadığıyla ilişkili olup olmadığının bilinmesi önemlidir (Johannes vd., 2009, s. 832). Bununla birlikte çalışanların işten ayrılma niyetlerinin artmasına veya azalmasına neden olabilecek örgütsel faktörler vardır. Örneğin örgütsel özdeşleşme bu faktörlerden biri sayılabilir ve işten ayrılma niyeti konusunda sinizmle başa çıkmada yardımcı olabileceği düşünülebilir (Polat ve Meydan, 2010, s. 146). Düzgün bir eğitim almadan işe yeni başlayan çalışanlar görevlerini yerine getirmek için gerekli bilgileri alamadıklarından dolayı işleri için gerekli olan becerileri gösteremezler. Uygun eğitimi alan çalışanlar, almayanlara göre mevcut işlerinde kalmaya daha yatkındırlar (Elnaga ve Imran, 2013, s. 134).

Çalışanın işinden ne derece tatmin olduğunu ölçmek zordur fakat imkansız değildir. Çalışanın iş tatmini örgütten neyi istediği ve bunun karşıllğında neler kazanmayı beklediğine bağlıdır. Çalışan örgüte verdiği hizmet karşılığında aldığı ücreti kendisine yakın statüde çalışan diğer çalışanların ücretleriyle karşılaştırır (Nergiz ve Yılmaz, 2016, s. 51). Diğer taraftan örgütte çalışanlar diğer çalışanlarla eşit muamele görmediklerini düşündükleri zaman kolay tatmin olamazlar. Bazı çalışanlar sadece az çalışmak durumunda oldukları işlerden tatmin olurlar. Kaynağı her ne olursa olsun iş tatminsizliği sonuçta örgütün için birçok sorunla karşı kalacağının göstergesidir. Bu sorunlara örnek olarak yüksek devamsızlık, çalışan devir hızında artış, yabancılaşma, kırgınlık ve düşük firma sadakati sayılabilir (Özgan vd., 2012, s. 34). Çalışanların iş tatminsizliğinin örgüte karşı olan dış ve iç tehditlere verilecek tepkileri zayıflattığı öngörülmektedir. İş tatminsizliğinin çalışanda isteksizlik duygusu oluşturarak devamsızlık yapma durumunun artmasına, verimliliğin düşmesine ve işten uzaklaşarak işten ayrılma niyetinin artmasına neden olduğu düşünülmektedir (Tekingündüz ve Tengilimoğlu, 2013, s. 79). Yöneticiden ve işin kendisinden tatmin olma durumu ile işten ayrılma niyeti arasında ilişki olduğu konusunda önemli kanıtlar bulunmaktadır (Tak ve Çiftçioğlu, 2008, s. 159).

\subsection{2. Ücret}

Ücret memnuniyeti, hem çalışanlar hem işverenler açısından birincil önemli bir konudur. Çalışanlar açısından ücret ekonomik gereksinimleri karşılamak bakımından bariz bir öneme sahiptir. Çalışanların ücretlerinden tatmin olmaları onların tutum ve davranışlarını etkiler. Birçok örgüt için işgücünün işten ayrılması, diğer faktörlerin yanında zaman ve para ile ilgili olduğu için asıl endişe verici konudur (Suğur vd., 2008, s. 162). Ödül ve ücret yönetimi insan kaynakların birimlerinin en önemli 
konularından biridir. Çünkü bir çalışanın çalıştığı işte devam etmesini sağlayan en önemli etkenlerden biri çalışmasının karşılığında aldığı ücretin hak ettiği tutarda olmasıdır. Çalışan aldığı ücretin, hak ettiği miktarda olduğunu düşünmezse işine devam etmek istemeyebilir. Her bir çalışan örgüte bilgisi ve yetenekleri dahilinde katkıda bulunur. Çalışanın örgütteki ücret ve ödül dağılımı konusunda adil davranıldığını düşünmesi için kendisiyle aynı işi yapan başka bir çalışanın gelirini karşılaştırması sonucunda tatmin olabilmesi gerekmektedir (Örücü ve Kışlalıoğlu, 2014, s. 48). Çalışanlar yaşam standartlarını yükseltmek için daha fazla ücret talep ederken, örgüt yöneticileri de ücret düzeyini giderler artmasın diye düşük tutmaya çalışırlar. Örgütün içinde bulunduğu koşullar ve çalışanların beklentileri dikkate alınarak uygun bir ücret belirlemek çalışanların örgütteki verimliliği üzerinde arttırıcı etki yaratmaktadır (Özdemir vd., 2016, s. 60).

\subsubsection{Stres}

Çalışanının çevresiyle olan etkileşimi neticesinde ortaya çıkan gerilim iş stresi olarak ifade edilebilir. Bazı çalışmalarda çalışanın iş stresi yaşamasına çevresinin onun üzerinde yarattı̆̆ baskının neden olduğu ileri sürülmüştür (Efeoğlu ve Özgen, 2006, s. 238). Aynı zamanda stres psikolojik bir kavramdır ve stres yaratan olgulara karşı bir tepkidir (Beehr ve Newman, 1978, s. 666). Motowidlove arkadaşları (1986, s. 618-629), stresi endişe, rahatsızlık, korku, depresyon ve keder gibi hoş olmayan bir duygusal deneyim olarak ifade etmişler ve stresin iş yaşamında iş performansı üzerindeki etkilerini araştırmışlardır. Çalışanlar mali açılardan kendilerini güvende hissetmediklerinden dolayı strese girebilir ve finansal nedenlerle örgütten ayrılabilirler. Başka bir şekilde örgütteki rolün ne olduğunun bilinmemesi de çalışanı strese girmesine neden olabilir (Qureshi vd., 2012, s. 232). Çalışma ortamındaki stres kaynakları ve olumsuzluklar çalışanların işe devam etme isteklerinin azalmasına ve performanslarının düşmesine neden olur (Tütüncü ve Demir, 2003, s. 150). Stresin çalışanların tatmin, verimlilik ve davranışları üzerinde doğrudan etkisi bulunmaktadır (Onay ve Kı1cı, 2011, s. 364).

\subsubsection{Fazla İş Yükü}

Aşırı iş yükü, örgütte çalışanların yerine getirebileceklerinden daha fazla iş talep edilmesidir. Örgütlerdeki eleman azlığı, dönemsel iş yoğunluğu veya örgütün çalışanlarını ekonomik nedenle işten ayırması nedeniyle mevcut çalışanlar üzerine aşırı iş yükü binmesi çalışan psikolojisi açısından önemlidir (Uysal vd., 2015, s. 942). Dolayısıyla, Jones vd., (2007, s. 663)'ne göre aşırı iş yükü, işten ayrılma niyetini etkileyen bir faktördür.

\section{2. Çevresel Nedenler}

İşletme dışında gelişen bazı faktörler işten ayrılma niyetine etki edebilirler. Ülkenin içinde bulunduğu ekonomik durum, sektörler arası iş gücü değişimi ve ekonomik istikrarsızlıklar gibi sorunlar çalışanların işten ayrılma niyetleri üzerinde etkili olabilir (Tütüncü ve Demir, 2003, s. 149). İş̦ten ayrılma süreçlerinde kurum içi problemlerin yanı sıra kurum dış1 çevresel faktörlerin de önemli etkileri olduğu görülmektedir. Çevresel faktörlerin etkili olduğu durumlarda işverenlerin işten ayrılmayı engelleyemediği görülmektedir. Ayrıca ekonomik krizlerin olduğu ve işsizlik oranının yüksek olduğu dönemlerde, alternatif iş imkanlarının az olması işten ayrılma niyetini etkileyebilir ve azaltabilir (Gürbüz ve Bekmezci, 2012, s. 190). İşten ayrılma niyeti kavramını anlamaya çalışırken alternatif iş olanaklarının da önemini hesaba katmak gerekir (Arnold ve Feldman, 1982, s. 353). Alternatiflerin algılanması ve değerlendirilmesi bireysel işten ayrılma süreci için çok önemlidir (Mobley vd.,1979, s. 494). Lee ve Mowday (1987, s. 722)'e göre alternatif iş imkanlarının işten ayrılma niyeti üzerinde etkisi olabilir.

\subsection{Bireysel Nedenler}

Çalışanlarda işten ayrılma niyetinin azalması hem kendilerinin hem de çalıştıkları kurumun ileride başarılı yerlerde olacağına inanması ile gerçekleşebilir. Başarısızlık algısı çalışanların aynı zamanda verimlerine de olumsuz etki eder aynı zamanda örgütsel bağlılık algısını da zedeler. Böylece çalışanlar farklı işlere yönelme eğilimi göstermektedirler. (Meydan ve Polat, 2010, s. 125). Etraftaki farklı işletmeler sundukları firsatlar ile çalışanların işten ayrılma niyetlerini etkileyebilir. Daha genel olarak bakıldığında çalışan, işi ile ilgili her konuyu ayrı ayrı değerlendirmektedir ve mevcut yaptığı iş ile alternatif seçenekleri arasında bir seçim yaparak buna göre işten ayrılma veya devam etme kararına 
varmaktadır (Örücü ve Kışlalığlu, 2014, s. 47). Bireysel nedenlerin ve işten ayrılma niyetine etkisi üzerine pek çok çalışma yapılmıştır. Bu çalışmalar Tablo 2.'de ki gibidir:

Tablo 2. Işsten Ayrılma Niyeti Bireysel Nedenleri Üzerine Yapılmış Çalışmalar

\begin{tabular}{|c|c|c|}
\hline Etken & Çalışma & Kaynak \\
\hline & $\begin{array}{l}\text { Birçok araştırma işten ayrılma niyeti ve yaş faktörünün olumsuz } \\
\text { ilişkiye sahip olduğunu ortaya koymaktadır }\end{array}$ & $\begin{array}{l}\text { Mobley } \\
1979, \quad \text { s. } \\
\text { 522. }\end{array}$ \\
\hline$\stackrel{\pi}{\pi}$ & $\begin{array}{l}\text { yaşlılara göre gençlerin daha fazla beklenti içinde olmaları, sabırsız } \\
\text { yapıda olmaları ve sosyal hayatlarına zaman ayırmak istemeleri işten } \\
\text { ayrılma niyetine girmelerine neden olabilir }\end{array}$ & $\begin{array}{l}\text { Sarığlan, } \\
\text { 2010:200-213. }\end{array}$ \\
\hline \multirow[b]{2}{*}{ 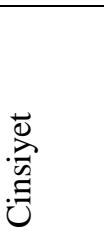 } & $\begin{array}{l}\text { çalışmada kadın ve erkeklerin işten ayrılma eğilimi birbirine benzer } \\
\text { olarak bulunmuştur. }\end{array}$ & $\begin{array}{l}\text { Griffeh } \\
2000, \quad \text { v. } 363- \\
488 .\end{array}$ \\
\hline & $\begin{array}{l}\text { Çalışan kadınların sorumluluklarının fazla olması nedeni ile çalışma } \\
\text { hayatına adapte olması zor bir süreçtir. Bu nedenle kadınların erkeklere } \\
\text { nazaran işten ayrılma niyeti daha fazladır. }\end{array}$ & $\begin{array}{l}\text { Örücü vd., } \\
\text { 2007:117-135. }\end{array}$ \\
\hline \multirow{2}{*}{ 总: } & $\begin{array}{l}\text { çalışmalar görev süresi ile işten ayrılma niyeti arasında negatif bir ilişki } \\
\text { olduğunu göstermektedir }\end{array}$ & $\begin{array}{l}\text { Mobley } \\
1979, \quad \text { s. } 493- \\
522 .\end{array}$ \\
\hline & $\begin{array}{l}\text { Örgütte uzun zamandır çalışanlar, yeni çalışmaya başlayanlara göre az } \\
\text { seviyede ayrılma niyeti eğilimi göstermektedir }\end{array}$ & $\begin{array}{l}\text { Eroğlu, 2014, s. } \\
147-160 .\end{array}$ \\
\hline \multirow{2}{*}{ 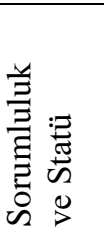 } & $\begin{array}{l}\text { medeni durumu da içeren aile sorumluluğu işten ayrılma davranışının } \\
\text { azalmasıla ilişkilendirilmiştir. }\end{array}$ & $\begin{array}{l}\text { Mobley } \\
1979, \quad \text { s. } 493- \\
522 .\end{array}$ \\
\hline & $\begin{array}{l}\text { çalışanın bir ailenin üyesi olması ve bir örgütün üyesi olmasındaki } \\
\text { rolleri arasında uyumsuzluk olabilir ve iş-aile yaşam çatışma } \\
\text { yaşanabilir }\end{array}$ & $\begin{array}{l}\text { Efeoğlu ve } \\
\text { Özgen, 2007, s. } \\
\text { 237-254. }\end{array}$ \\
\hline
\end{tabular}

\section{3. İşten Ayrılma Niyetinin Önlenmesi}

İşten ayrılma niyeti sürekli üzerinde durulduğu gibi ayrılma davranışının gerçekleşmesinin ana sebebi olarak düşünülür. Bundan dolayı işten ayrılma niyetine sebebiyet veren sorunların incelenerek çözüme kavuşturulması gerekir. Aksi takdirde bu durumun kuruma ciddi sonuçları olacaktır. Araştırmacılar, işten ayrılmanın değil işten ayrılma niyetinin araştırılmasının daha önemli olduğunu ileri sürmüşlerdir. Burada amaç hem diğer çalışanları etkileyebilecek davranışları engellemek hem de işten ayrılmanın getireceği maliyetleri azaltmaktır. Eğer liderler çalışanların işten ayrılma maliyetlerini azaltmak isterlerse bir sonraki adımları çalışanların desteklerini geliştirici faaliyetlerde bulunmak olmalıdır (Hughes vd., 2010, s. 352). Örgütlerde insan kaynağının işten ayrılmasını önlemek insan kaynakları yönetiminin önemli alanlarından birisi konumundadır. İşletmeler için uygun çalışanı bulmak kadar onu elde tutmakta önemli hale gelmiştir (Beğenirbaş ve Çalışkan, 2014, s. 110). Örgütlerdeki insan kaynakları uygulamaları çalışanların becerilerini etkiler ve insan kaynağının gelişimine katkıda bulunur. Gelişim ve eğitim programları görevi başarı ile tamamlama olasılı̆̆ını arttırarak, çalışanların bireysel yetenekleri ve kariyer planları arasında bağlantı kurmasına yardımcı olur ve işten ayrılma niyetlerini azaltabilir.

Küreselleşme, işgücü çeşitliliği ve teknolojik gelişmeler nedeniyle bugün çalışma koşulları eskisine göre değişmiştir. Artık insanlar daha fazla iş imkanı bulabilmektedirler. Yöneticilerin en iyi çalışanlarını elde tutmaları zor bir hal almaya başlamıştır. Örgütler çalışanlarıyla iletişim kanallarını açık tuttuklarında ve çalışanlarıyla daha fazla bilgi paylaştıklarında çalışanların işten ayrılma niyetinin de azalması olasıdır (Chang vd., 2013, s. 7). Diğer taraftan Gim ve arkadaşları (2015, s. 669) örgütteki rekabetçi psikolojik ortamın işten ayrılma niyetini olumlu yönde etkilediğini ve bu nedenle kural koyucuların rekabetçi ortamı cesaretlendirmemelerini ve duygusal bağl1lı̆̆ teşvik etmeleri gerektiğini ifade etmişlerdir. 
İşten ayrılmanın gerçekleşmesi sonucunda kurumların katlanacağ maliyetleri minimuma indirmek amacıyla uygulayacağı birtakım stratejiler vardır bunları şu şekilde açıklayabiliriz (Çarıkçı ve Çelikkol, 2009, s. 158);

- Çalışan tespitinin yerinde ve doğru şekilde yapılarak bilgi ve beceriye yönelik işe alımların gerçekleştirilmesi konusunda çalışmalar yapılmalıdır.

- Kurumsal bağlılığın pekiştirilmesi için çalışanların işe ilk başladıkları süreçlerden yola çıkarak birbirleri ile uyum ve güven içinde çalışacakları ortamın oluşturulması.

- Çalışanların içinde bulundukları kurumda gelecek görmeleri çok önemlidir. Bundan dolayı kariyerlerindeki gelişime destek sağlayacak olanakların ve terfi imkânlarının verilmesi motive edici bir çalışma olacaktır.

- $\quad$ Grup çalışmaları çok önemlidir ve bu konuda çalışanlar teşvik edilmelidir. Ücret gibi temel konular net olmalı bu konular hakkındaki memnuniyetlerin anketler ile belli aralıklarda ölçülmesi gerekmektedir.

- $\quad$ Ödüllendirme konusunda bireysel davranılmalı her çalışanın farklı bir motivasyon şekli olduğu unutulmamalıdır. Bireysel olarak düşünülüp hazırlanan bir ödül sistemi kurumsal ödülden daha motive edici olmaktadır.

- $\quad$ Kurum içindeki sorunların çözüm aşamasına bütün çalışanlar dâhil edilmeli bu şekilde kurumsal aidiyet duygusuna katkı sağlanmalıdır.

\section{4. İşten Ayrılma Niyetinin Sonuçları}

Hem araştırmacılar hem de uygulayıcılar çalışanların işten ayrılma bu sorununa daha iyi çözüm bulma çabaları için önemli miktarda zaman ve kaynak ayırmaktadır (Hemdi ve Nasurdin, 2006, s. 22). İş görenler kimi zaman kendi istekleri ile kimi zaman da kurumsal nedenler ile işten ayrılabilmektedir. Önemli olan kısım gönüllü olarak ayrılmaların neden gerçekleştiğidir. İşten gönüllü veya gönülsüz nedenlerle işten ayrılmalar olabilir. $\mathrm{Bu}$ durum çalışan devir hızını etkilemektedir. Devir hızı maliyetleri arttır ve karlılığı düşürebilir. Çalışan açısından düşük performansa ve tatminsizliğe yol açabilir (Yılmaz ve Halıc1, 2010, s. 95). Günümüz rekabetçi ortamında örgütleri tarafindan çalışan devir hızını yönetmek önemli olarak görülmektedir. Doğal olarak çalışanlarda hayatlarında farklılık isterler, farklı ve yeni bir görev veya daha iyi bir çalışma ortamı arayabilirler.

Bireysel sebepler ile gerçekleşen ayrılmaların kuruma maliyetleri oldukça yüksek olmakta ve bu tür ayrılma sayısı arttıkça işletme içinde ciddi sorunlar olduğu ortaya çıkmaktadır. Kurum içinde işten ayrılma oranının istihdam oranından fazla olması durumunda işletme ciddi zararlara uğramaktadır. $\mathrm{Bu}$ zararlar önemli bazı alanlarda personelin bulunması bu personelin eğitimi gibi durumları beraberinde getirmektedir. Diğer bir etkisi ise uzun vadede diğer çalı̧̧anlara da sirayet eden performans düşüklükleridir (Elçi ve Karabay, 2016, s. 126).

İşten ayrılma niyeti, daha öncede belirtildiği gibi bir çalışanın çalışmış olduğu örgütten ayrılma isteği olarak tanımlanır (Chang vd., 2013, s. 11). Çalışanın işten ayrılma durumu sonucunda karşılaştığı olumsuz durumlar da söz konusudur. Bu durumlara örnek olarak, iş görenin yeni bir iş başvurusunda bulunduğu sırada, en son işinden neden ayrıldığı hakkında negatif bir algı oluşabilmesidir. Bu durum aynı zamanda kuruma karşı ne kadar bağlı olduğu konusunda da soru işaretlerine yol açmaktadır (Y1lmaz ve Halıc1, 2010, s. 105).

Çalışanları elde tutmak için çalışanlara ekonomik koşullar sunmak örgüt için zahmetli ve zordur. Fakat her hangi bir örgütün nitelikli işgücünü de elinde tutabilmesi örgüt için çok önemlidir. Her örgüt karlı olmak için, yüksek verimlilik ve düşük iş̧ücü devir hızı ister (Shamsuzzoha ve Shumon, 2007, s. 64). İşü̈cünün etkinliğini ve verimliliğini sağlamak bireyin işine karşı duyduğu hoşnutluğu arttırarak, onun motivasyonunu yükselterek sağlanır (Şimşek vd., 2014, s. 166). İster gönüllü ister gönülsüz olsun işten ayrılmalar hem işçi hem de örgüt açısından bir takım maliyetler doğurmaktadır (Kirschenbaum ve Weisberg, 2002, s. 109).

Çalışanlar kişisel beklenti ve ihtiyaçları karşılandığında ve işlerinden ayrılmayı gerektirecek herhangi bir durum ortaya çıkmadığında işlerine devam ederler ve işten ayrılma niyeti içine girmezler. Çalışanların işte kalma niyetinde olmaları hem kişisel hem de örgütsel amaçların gerçekleştirilmesinde olumlu sonuçlar doğurabilir (Yasım vd., 2016, s. 554). 


\section{5- Toksik Liderlik ile İşten Ayrılma Niyeti Arasındaki İlişki}

Aubrey, (2012, s. 1-30) çalışmasında toksik davranışın kurum ve çalışana kalıcı zarar verdiğini belirtmiştir. Yapılan bazı çalışmalar ise toksik liderliğin iş yeri stresini artırdığı ve bu yüzden işten ayrılma niyetine sebebiyet verdiği yönünde olmuştur (Hadadian ve Zarei, 2016, s. 84-89; Unur ve Pekerşen, 2017, s. 108-129).

Toksik davranış ve duygu hissi çalışanlara hem fiziksel hem de duygusal anlamda vermektedir. Bu durum doğal olarak önce örgütsel sessizliğe ardından örgüt bağının azalmasına ve nihayetinde işten ayrılma niyetine sebep olmaktadır. Appelbaum ve Roy-Girard, (2007, s. 17-28), toksik davranışın çalışanlar üzerinde anksiyete benzeri psikolojik sıkıntılara yol açtığını belirterek, işten ayrılmalara neden oluğunu vurgulamıştır. Yazar yapmış olduğu nicel çalışmada Kuzey Amerika'da ki bir şirketin toksik davranış sonucu büyük kısmı çalışan kaynaklı 200 milyar dolar kayba uğradığını vurgulamıştır.

Toksik liderlik davranışı iş tatmininin ana kaynağı olan övülme ve takdir edilme gibi kavramları yok ettiğinden bu tür örgütlerde çalışanlar iş tatminsizliği yaşamaktadır. Bu durum beraberinde performans düşüklüğüne ve işten ayrılma niyetine yol açabilmektedir (Erdil vd., 2011, s. 19).

Örgütten ayrılma veya örgütte kalma niyeti ile mesleki bağlılık arasında yakın ilişki vardır. Bu alanda yapılan bazı çalışmalar mesleki bağl1lık seviyesi yüksek bireylerin işten ayrılma niyeti eğilimlerinin daha düşük olduğu ve örgütlerine olan bağlllıklarının yüksek olduğu göstermektedir (Tak ve Çiftçioğlu, 2008, s. 157).

Örgütsel bağl1lı incelendiğinde işe bağlılık, işten ayrılma niyeti, devamsılılk gibi ölçüleri gözlemlemek mümkündür. Bu sonuçlar karşımıza olumlu veya olumsuz şekillerde çıkabilir. Örgütüne aşırı bağlılık duyan bir birey örgüt performansına olumlu yönde katkı sağlarken aşırı bağl11ık gösteren bireyler devamsızlık veya işten ayrılma gibi şirket performansına olumsuz etki edecek durumlardan da uzaklaşmaktadırlar (Balay, 2000, s. 27).

Frost'a (2004, s. 113) göre ise; toksik duygu, örgütün tümünden ve bireylerinden enerjiyi alıp tüketen, örgüt ile ilgili önemli tarihlerin kaçırılmasına ve örgüt için önemli personellerin işi terk etmesine sebep olacak biçimde davranan zarar veren bir madde gibidir. Eğinli ve Bitirim'e (2010, s. 47) göre, toksik liderler kurumlarına karşı olumsuzluk yaşatabilen liderlerdir. Kişiler, kurumlarına karşı bağlılıklarını yitirmeye başladıklarında kuruma olan katkıları azalacaktır ve kurum bundan zarar görebilecektir. Kurum çalışanları toksik liderlerine ya boyun eğecek ya da kurumu terk etme seçeneğini kullanacaklardır. Kurumun idealden uzaklaştığını düşünenler ayrılmayı tercih ederken, diğerleri liderin davranışlarının normal olduğunu düşünürler ve kalırlar. Fakat kurumda stres düzeyi yüksektir.

Mailtis ve Özçelik, (2004, s. 375-393) çalışmalarında toksik ve örgütsel karar verme süreçlerini incelemişler ve toksik davranışın çalışanların karar verme süreçlerine negatif etki ettiği sonucunu elde etmişlerdir. Yazarlar bu durumun örgüt ortamından bir an önce uzaklaşma isteği ile düşünmeden örgütü terk etme gibi sonuçlara yol açabileceğini öngörmüşlerdir.

\section{KAYNAKÇA}

Arnold, H. J., \& Feldman, D. C. (1982). A multivariate analysis of the determinants of job turnover. Journal of applied psychology, 67(3), 350-360.

Appelbaum, S. H., \& Roy-Girard, D. (2007). Toxins in the workplace: affect on organizations and employees. Corporate Governance: The international journal of business in society, 7(1), 17-28.

Aubrey, D. W. (2012). The effect of toxic leadership. UK:Army War Coll Carlisle Barracks Pa.

Balay, R. (2000). Yönetici ve ögretmenlerde örgütsel bağlllık. Ankara: Nobel. 
Beehr, T. A., \& Newman, J. E. (1978). Job stress, employee health, and organizational effectiveness: A facet analysis, model, and literature review 1. Personnel psychology, 31(4), 665-699.

Beğenirbaş, M., \& Çalışkan, A. (2014). Duygusal emeğin iş performansı ve işten ayrılma niyetine etkisinde kişilerarası çarpıklığın aracılık rolü. Business and Economics Research Journal, 5(2), 109-127.

Chang, W. J. A., Wang, Y. S., \& Huang, T. C. (2013). Work design-related antecedents of turnover intention: A multilevel approach. Human Resource Management, 52(1), 1-26.

Cotton, J. L., \& Tuttle, J. M. (1986). Employee turnover: A meta-analysis and review with implications for research. Academy of management Review, 11(1), 55-70.

Çarıkçı, İ. H., \& Çelikkol, Ö. (2009). İş-aile çatışmasının örgütsel bağlılık ve işten ayrılma niyetine etkisi. Süleyman Demirel Üniversitesi Sosyal Bilimler Enstitüsü Dergisi, (9), 153-170.

Efeoğlu, İ. E., \& Özgen, H. (2006). İş-aile yaşam çatışmasının iş stresi, iş doyumu ve örgütsel bağll11k üzerindeki etkileri: ilaç sektöründe bir araştırma. Çukurova Üniversitesi Sosyal Bilimler Enstitüsü Dergisi, 16(2), 237-254.

Elçi, M. \& Karabay, M. E. (2016). İşletmelerde yıldırmaya maruz kalma algısının çalışanların işten ayrılma niyetine ve örgütsel sessizlik davranışlarına etkisi: hizmet sektörü üzerine bir araştırma. Yönetim ve Ekonomi Araştırmaları Dergisi, 14(1), 125-149.

Elnaga, A., \& Imran, A. (2013). The effect of training on employee performance. European Journal of Business and Management, 5(4), 137-147.

Erdil, O., Keskin, H., İmamoğlu, S. Z., \& Erat, S. (2011). Yönetim tarzı ve çalışma koşulları, arkadaşlık ortamı ve takdir edilme duygusu ile iş tatmini arasındaki ilişkiler: Tekstil sektöründe bir uygulama. Doğuş Üniversitesi Dergisi, 5(1), 17-26.

Ertürk, M. (2009). Issletmelerde yönetim ve organizasyon. İstanbul: Beta Basım Yayım.

Findıkçı, İ. (2006). İnsan kaynakları yönetimi. İstanbul: Alfa Yayınc1lı.

Frost, P. J. (2004). Handling toxic emotions:: new challenges for leaders and their organization. Organizational Dynamics, 33(2), 111-127.

Gaertner, S. (1999). Structural determinants of job satisfaction and organizational commitment in turnover models. Human resource management review, 9(4), 479-493.

Gim, G. C., Desa, N. M., \& Ramayah, T. (2015). Competitive psychological climate and turnover intention with the mediating role of affective commitment. Procedia-Social and Behavioral Sciences, 172, 658-665.

Goldman, A. (2006). High toxicity leadership: Borderline personality disorder and the dysfunctional organization. Journal of Managerial Psychology, 21(8), 733-746.

Griffeth, R. W., Hom, P. W., \& Gaertner, S. (2000). A meta-analysis of antecedents and correlates of employee turnover: Update, moderator tests, and research implications for the next millennium. Journal of management, 26(3), 463-488.

Gürbüz, S., \& Bekmezci, M. (2012). İnsan kaynakları yönetimi uygulamalarının bilgi işçilerinin işten ayrılma niyetine etkisinde duygusal bağll1ı̆̆ın aracıllk ve düzenleyicilik rolü. Istanbul Business Research, 41(2), 189-213.

Hadadian, Z., \& Zarei, J. (2016). Relationship between toxic leadership and job stress of knowledge workers. Studies in Business and Economics, 11(3), 84-89.

Hemdi, M. A., \& Nasurdin, A. M. (2006). Predicting turnover intentions of hotel employees: The influence of employee development human resource management practices and trust in organization. Gadjah Mada International Journal of Business, 8(1), 21-42. 
Houkes, I., Janssen, P. P., Jonge, J., \& Bakker, A. B. (2003). Specific determinations of intrinsic work motivation, emotional exhaustion and turnover intention: A multisample longitudinal study. Journal of Occupational and Organizational Psychology, 76(4), 427-450.

Hughes, L. W., Avey, J. B., \& Nixon, D. R. (2010). Relationships between leadership and followers' quitting intentions and job search behaviors. Journal of Leadership \& Organizational Studies, 17(4), 351-362.

Jackofsky, E. F. (1984). Turnover and job performance: An integrated process model. Academy of Management review, 9(1), 74-83.

Johannes, A.V., van der Heijden, Marloes L. van Engen and Jaap Paauwe, (2009). Expatriate career support: Predicting expatriate turnover and performance. The International Journal of Human Resource Management, 20(4), 831-845.

Jones, E., Chonko, L., Rangarajan, D., \& Roberts, J. (2007). The role of overload on job attitudes, turnover intentions, and salesperson performance. Journal of Business Research, 60(7), 663-671.

Joo, B. K., \& Park, S. (2010). Career satisfaction, organizational commitment, and turnover intention: The effects of goal orientation, organizational learning culture and developmental feedback. Leadership \& Organization Development Journal, 31(6), 482-500.

Kirschenbaum, A., \& Weisberg, J. (2002). Employee's turnover intentions and job destination choices. Journal of Organizational Behavior, 23(1), 109-125.

Lee, T. W., Mitchell, T. R., Sablynski, C. J., Burton, J. P., \& Holtom, B. C. (2004). The effects of job embeddedness on organizational citizenship, job performance, volitional absences, and voluntary turnover. Academy of Management journal, 47(5), 711-722.

Lee, T. W., \& Mowday, R. T. (1987). Voluntarily leaving an organization: An empirical investigation of Steers and Mowday's model of turnover. Academy of Management journal, 30(4), 721-743.

Loi, R., Hang-Yue, N., \& Foley, S. (2006). Linking employees' justice perceptions to organizational commitment and intention to leave: The mediating role of perceived organizational support. Journal of Occupational and Organizational Psychology, 79(1), 101-120.

Maitlis, S., \& Ozcelik, H. (2004). Toxic decision processes: A study of emotion and organizational decision making. Organization Science, 15(4), 375-393.

Mobley, W. H., Griffeth, R. W., Hand, H. H., \& Meglino, B. M. (1979). Review and conceptual analysis of the employee turnover process. Psychological Bulletin, 86(3), 493-522.

Morrison, J. F. (2014). A time to think, a time to talk: Irish Republican prisoners in the Northern Irish peace process. In Prisons, Terrorism and Extremism (pp. 97-108). UK:Routledge.

Motowidlo, S. J., Packard, J. S., \& Manning, M. R. (1986). Occupational stress: its causes and consequences for job performance. Journal of applied psychology, 71(4), 618-629.

Nergiz, E., \& Yılmaz, F. (2016). Çalışanların iş tatmininin performanslarına etkisi: Atatürk havalimanı gümrüksüz satış işletmesi örneği. Kastamonu Üniversitesi İktisadi ve İdari Bilimler Fakültesi Dergisi, 14(4), 50-79.

Onay, M., \& Kılcı, S. (2011). İş stresi ve tükenmişlik duygusunun işten ayrılma niyeti üzerine etkileri: garsonlar ve aşçıaşılar. Organizasyon ve Yönetim Bilimleri Dergisi, 3(2), 363-372.

Örücü, E., \& Kışlalığlu, R. (2014). Örgütsel bağl11ık üzerine bir alan çalışması. Uluslararası Yönetim Iktisat ve Işletme Dergisi, 10(22), 45-65.

Özdemir, L., Erdem, H., \& Kalkın, G. (2016). Kamu çalışanlarının güvenlik iklimi algılarının iş tatmini ve iş performansı üzerine etkisi. Süleyman Demirel Üniversitesi Vizyoner Dergisi, 7(15), 59-69.

Özer, G., \& Günlük, M. (2010). Örgütsel adaletin muhasebecilerin iş memnuniyeti ve işten ayrılma eğilimlerine etkisi. Gaziantep Üniversitesi Sosyal Bilimler Dergisi, 9(2), 459-485. 
Özgan, H., Özgan, H., Külekçi, A.., \& Külekçi, E. (2012). Öğretim elemanlarının sessizlik nedenleri ve üniversitelerine etkileri. E-Uluslararası Eğitim Araştırmaları Dergisi, 3(4), 33-49.

Polat, M., \& Meydan, C. H. (2010). Örgütsel özdeşleşmenin sinizm ve işten ayrılma niyeti ile ilişkisi üzerine bir araştırma. Savunma Bilimleri Dergisi, 9(1), 145-172.

Poyraz, K., \& Kama, U. B. (2008). Algılanan iş güvencesinin, iş tatmini, örgütsel bağll1ık ve işten ayrılma niyeti üzerindeki etkilerinin incelenmesi. Süleyman Demirel Üniversitesi Ikktisadi ve İdari Bilimler Fakültesi Dergisi, 13(2), 143-164.

Qureshi, I., Jamil, R., Iftikhar, M., Arif, S., Lodhi, S., Naseem, I., \& Zaman, K. (2012). Job stress, workload, environment and employees turnover intentions: Destiny or choice. Archives of Sciences (Sciences Des Archives), 65(8), 230-241.

Rousseau, D. M., \& McLean Park, J. (1993). The contracts of individuals and organizations. Research In Organizational Behavior, 15, 1-43.

Sarıoğlan, M. (2010). Otel işletmeleri yiyecek-içecek ünitelerinde işgören devri üzerine görgül bir araştırma. Adlyaman Üniversitesi Sosyal Bilimler Enstitüsü Dergisi, (5), 200-213.

Senge, P. M. (2011). Beşinci disiplin. (A. İldeniz , \& A. Doğukan, Çev.) İstanbul: Yapıkredi Yayınları.

Shamsuzzoha, A.H. M., \& Shumon, M. R. H. (2007). Employee turnover- a study of its causes and effects to different industries in Bangladesh. Manufacturing Engineering/Vyrobne Inzinierstvo, 6(3), 64-68.

Spencer, D. G. (1986). Employee voice and employee retention. Academy of Management Journal, 29(3), 488-502.

Suğur, N., Suğur, S., \& Şavran, T. G. (2008). Türkiye'de orta sınıfın mazbut hizmetkârları: kapıcılar, gündelikçiler ve çocuk bakıcıları. Ankara Üniversitesi SBF Dergisi, 63(03), 161-183.

Şimşek, M., Akgemci, T., \& Çelik, A. (2008). Davranış bilimlerine giriş ve örgütlerde davranış. Ankara: Gazi Kitabevi.

Tak, B., \& Çiftçioğlu, B. A. (2008). Mesleki bağlılık ile çalışanların örgütte kalma niyeti arasındaki ilişkiyi incelemeye yönelik görgül bir çalışma. Ankara Üniversitesi SBF Dergisi, 63(4), 155-178.

Tekingündüz, S., \& Tengilimoğlu, D. (2013). Hastane çalışanlarının iş tatmini, örgütsel bağlılık ve örgütsel güven düzeylerinin belirlenmesi. Sayistay Dergisi, 77-103.

Tett, R. P., \& Meyer, J. P. (1993). Job satisfaction, organizational commitment, turnover intention, and turnover: path analyses based on meta-analytic findings. Personnel psychology, 46(2), 259-293.

Tütüncü, Ö., \& Demir, M. (2003). Konaklama işletmelerinde insan kaynakları kapsamında işgücü devir hızının analizi ve Muğla bölgesi örneği. Dokuz Eylül Üni. SBE Dergisi, 5(2), 146-169.

Unur, K., \& Pekerşen, Y. (2017). İş stresi ile toksik davranışlar arasındaki ilişki: Aşçılar üzerinde bir araştırma. Seyahat ve Otel İ̧̧letmeciliği Dergisi, 14(1), 108-129.

Uysal, H. T., Akbulut, H., \& Ertan, S. (2015). Aşırı iş yükünün performans perspektifinden çalışma psikolojisinde negatifliğe etkisi: muhasebe meslek mensuplarına yönelik bir araştırma. Journal of International Social Research, 8(38), 942-950.

Yasım, Y. K., \& Adem, U. (2016). Bankacı kadınların örgütsel sinizmin algılarının ișten ayrılma niyetine etkisi: Ordu ili örneği. ODÜ Sosyal Bilimler Araştırmaları Dergisi (ODÜSOBİAD), 6(15), 554-572.

Yenihan, B., Mert, Ö.., \& Çiftyıldız, K. (2014). İş stresi ve işten ayrılma niyeti arasındaki ilişki: Otomotiv işletmesinde bir araştırma. Çalışma İliş̧kileri Dergisi, 5(1), 38-49.

Yıldırım, M. H., Erul, E. E., \& Kelebek, P. (2014). Tükenmişlik ile işten ayrılma niyeti arasındaki ilişki banka çalışanları üzerine bir araştırma. Organizasyon ve Yönetim Bilimleri Dergisi, 6(1), 34-44. 
Yılmaz, B., \& Halıcı, A. (2010). İşgücü devir hızını etkileyen etmenler: sekreterlik mesleğinde bir araştırma. Uluslararası Íktisadi ve İdari İncelemeler Dergisi, (4), 93-108.

Yozgat, U., Yurtkoru, S., \& Bilginoğlu, E. (2013). Job stress and job performance among employees in public sector in Istanbul: Examining the moderating role of emotional intelligence. ProcediaSocial and behavioral sciences, 75, 518-524. 